\title{
Novel Therapies for Relapsed or Refractory Diffuse Large B-Cell Lymphoma
}

\author{
Leonard Jeff Harris ${ }^{1, *(1)}$, Kruti Patel ${ }^{1}\left[\right.$ and Michael Martin ${ }^{2}$ \\ 1 Oncology Division, Department of Medicine, University of Tennessee Health Sciences Center, \\ Memphis, TN 38103, USA; kpatel@WESTCLINIC.com \\ 2 West Cancer Center \& Research Institute, Memphis, TN 38103, USA; mmartin@WESTCLINIC.com \\ * Correspondence: jeff.harris@uthsc.edu; Tel.: +1-901-674-6058
}

Received: 29 September 2020; Accepted: 10 November 2020; Published: 13 November 2020

\begin{abstract}
The most common type of non-Hodgkin lymphoma in adults is diffuse large B-cell (DLBCL). There is a historical unmet need for more effective therapies in the 2nd and 3rd line setting. Emerging immunochemotherapies have shown activity in small studies of heavily pre-treated patients with prolonged remissions achieved in some patients. Anti-CD19 CAR (chimeric antigen receptor) $\mathrm{T}$ cells are potentially curative in the 3rd line and beyond setting and are under investigation in earlier lines of therapy. Antibody-drug conjugates (ADC's) such as polatuzumab vedotin targeting the pan-B-cell marker $\mathrm{CD} 79 \mathrm{~b}$ has proven effectiveness in multiply-relapsed DLBCL patients. Tafasitamab (MOR208) is an anti-CD19 monoclonal antibody producing prolonged remissions when combined with Lenalidomide (LEN) in patients who were not candidates for salvage chemotherapy or autologous stem cell transplant. Selinexor, an oral, small-molecule selective inhibitor of XPO1-mediated nuclear export (SINE), demonstrated prolonged activity against heavily-pretreated DLBCL without cumulative toxicity and is being investigated as part of an oral, chemotherapy-free regimen for relapsed aggressive lymphoma. This article reviews current strategies and novel therapies for relapsed/refractory DLBCL.
\end{abstract}

Keywords: Relapsed or Refractory Diffuse Large B Cell Lymphoma; DLBLC; immunotherapy; chemotherapy-free regimen

\section{Introduction}

Diffuse large B-Cell Lymphoma (DLBCL) is an aggressive subtype accounting for $25-30 \%$ of Non-Hodgkin lymphoma (NHL) with an incidence of 5.6 per 100,000 persons per year [1,2]. DLBCL is usually symptomatic at presentation with either nodal or extranodal disease. Diagnosis is made when large, transformed B cells (CD19+, CD20+, CD79+) with prominent nucleoli, diffuse growth pattern, and a high proliferation fraction are seen on tissue biopsy [1]. The World Health Organization (WHO) schema classifies by cell of origin (COO) classification including germinal B-cell (GCB) subtype or activated $B$ cell $(A B C)$ subtype, but more recent transcriptome sequencing techniques have identified five distinct subtypes that improve the differentiation among prognostic groups in DLBCL [3,4]. Genomic instability is demonstrated by a median of 17 (range: $0-48$ ) genetic drivers that were clustered into these 5 distinct genetic signatures. In the 2017 revision of WHO classifications, DLBCL with translocations of MYC and BCL2 and/or BCL6 - double-hit (DHL) or triple-hit (THL) - are reclassified as Diffuse Aggressive B-Cell Lymphomas, with more intense therapeutic regimens such as DA-EPOCH-R with CNS prophylaxis in the first line setting having a 4 year overall survival of $72.2 \%$ [5]. Despite multiple studies attempting to improve upon the outcomes, $\mathrm{R}-\mathrm{CHOP}$ remains the first line treatment for DLBCL regardless of IPI score, $\mathrm{COO}$, or gene expression profile except for DHL. 
DLBCL cases that do not fit a specific subtype have an overall survival rate of $65 \%$ when treated with standard R-CHOP (Rituximab, Cyclosporine, Vincristine, Prednisone) therapy [1]. The Standard International Prognostic Index (IPI) is widely used for risk stratification with aggressive B-cell lymphoma, and has been validated with continued prediction of risk in the Rituximab era [6]. Patients with a high IPI score have poor prognosis with an OS as low as $20-25 \%$. Certain mutations and pathways are common in the GCB subtype such as EZH2, BCL2 and PI3K. In the ABC subtype, NF-KB activation, MYD88 mutations and JAK-STAT pathways are more common [7].

While most patients respond, $30-40 \%$ of patients with DLBCL relapse or are unable to achieve remission with first-line treatment. In these cases, the prognosis is poor [8]. Approximately $50 \%$ of patients with relapsed or refractory $(\mathrm{R} / \mathrm{R}) \mathrm{DLBCL}$ have a response to second-line chemotherapy; up to $50 \%$ of these patients proceed to undergo autologous hematopoietic stem-cell transplantation in some settings, and of these, approximately 30 to $40 \%$ remain progression-free 3 years after transplantation [8-12]. Median survival for primary and secondary refractory DLBCL is 5-7 months [8].

Patients who progress after receiving R-CHOP receive combination salvage chemotherapy. Commonly used regimens, including R-ICE, R-DHAP, R-GDP, R-GemOx, O-DHAP, O-ICE, and DR-ICE, have similar treatment effects $[13,14]$. However, analysis of real-world data from 126 community-based hematology/oncology practices in the US between 2010-2016 demonstrated that only 13\% of patients who received salvage regimens intended for ASCT eventually underwent ASCT [15].

The unmet need for more effective regimens is highlighted by the wide heterogeneity in regimens used in clinical practice with consistently poor outcomes [13]. Pts that are not candidates for ASCT and those who never make it or have failed CAR-T therapy have poor outcomes with salvage chemotherapy regimens. Response rate comparisons between studies are unreliable due different rates of enrollment of primary refractory disease. In the phase III CORAL trial $(n=396)$ comparing R-ICE and R-DHAP followed by autologous hematopoietic cell transplant (HCT) for chemosensitive patients, the overall response was $63 \%$, and the three year overall survival was $47 \%$. Median overall survival of R/R DLBCL who failed second-line regimens in CORAL was 4.4 months [8]. The LY.12 trial $(n=619)$ compared the platinum-containing regimens R-GDP and R-DHAP followed by autologous HCT and had response rate $45 \%$ [12]. SCHOLAR-1 is the most comprehensive analysis of pooled outcomes from several large studies of relapsed and refractory DLBCL $(n=636)$ treated with various standard of care chemotherapy regimens, and the ORR was $26 \%, \mathrm{CR}$ rate of $7 \%$, and median overall survival was 6.2 months $[16,17]$.

A cost-effectiveness analysis of DLBCL regimens from the Truven database with claims data from US government and private payers highlighted the direct costs associated with the $2 / 3$ of patients with DLBCL who received subsequent 2nd-line regimen after completing R-CHOP [18]. More effective treatment options for this resource intensive condition has the potential to both decrease mortality and reduce the costs of subsequent lines of therapy including ASCT $[18,19]$. Several innovative treatment modalities are already receiving regulatory approvals (Table 1 ). 
Table 1. Novel Regimens with FDA Approval.

\begin{tabular}{|c|c|c|c|c|c|c|c|}
\hline Agent & $\begin{array}{l}\text { Year of FDA } \\
\text { Approval }\end{array}$ & Regimen & Population & $\begin{array}{c}\text { Relapse }<1 \text { year } \\
\text { of DLBCL } \\
\text { Diagnosis }\end{array}$ & $\begin{array}{l}\text { Refractory } \\
\text { to Last } \\
\text { Regimen }\end{array}$ & DHL/THL & $\begin{array}{l}\text { Efficacy } \\
\text { Outcomes }\end{array}$ \\
\hline $\begin{array}{l}\text { Axicabtagene } \\
\text { ciloleucel } \\
\text { (axi-cel) }\end{array}$ & 2017 & Flu/Cy LD & $\begin{array}{l}\text { R/R DLBCL refractory to } 2 \\
\text { lines of therapy }\end{array}$ & $30 \%$ & $77 \%$ & NR & $\begin{array}{c}\text { ORR } 83 \% \\
\text { CR } 58 \% \\
\text { mOS } 24 \text { mos }\end{array}$ \\
\hline $\begin{array}{l}\text { Lisocabtagene } \\
\text { maraleucel }\end{array}$ & & Flu/Cy LD & $\begin{array}{l}\mathrm{R} / \mathrm{R} \text { DLBCL refractory to } 2 \\
\text { lines of therapy }\end{array}$ & NR & $44 \%$ & $13 \%$ & $\begin{array}{c}\text { ORR } 73 \% \\
\text { CR } 53 \% \\
\text { mOS }>12 \text { mos }\end{array}$ \\
\hline Tisagenlecleucel $^{\text {a }}$ & 2018 & $\begin{array}{c}\text { Flu/Cy LD } \\
\text { or Benda-Flu LD }\end{array}$ & $\begin{array}{l}\text { R/R DLBCL refractory to } 2 \\
\text { lines of therapy }\end{array}$ & NR & $40 \%$ & $27 \%$ & $\begin{array}{c}\text { ORR } 52 \\
\text { CR } 40 \% \\
\text { mOS } 12 \text { mos } \\
\end{array}$ \\
\hline $\begin{array}{c}\text { Polatuzumab } \\
\text { vedotin [20] }\end{array}$ & 2019 & Pola + BR & $\begin{array}{c}\mathrm{R} / \mathrm{R} \mathrm{DLBCL} \\
\text { Ineligible for ASCT }\end{array}$ & $53 \%$ & $75 \%$ & $0 \%$ & $\begin{array}{c}\text { CMR } 40 \% \\
\operatorname{mOS} 12.4 \text { mos }\end{array}$ \\
\hline Selinexor [21] & 2020 & $\begin{array}{c}\text { Selinexor } 60 \mathrm{mg} \text { po on } \\
\text { days } 1 \text { and } 3 \text { of each week }\end{array}$ & R/R DLBCL & $\begin{array}{l}33 \% \\
\S \S\end{array}$ & $72 \%$ & $4 \%$ & $\begin{array}{c}\text { ORR } 28 \% \\
\text { CR } 12 \% \\
\text { mOS } 9.1 \text { mos }\end{array}$ \\
\hline Tafasitamab [22] & 2020 & Tafa + LEN $25 \mathrm{mg}$ & $\begin{array}{c}\text { R/R DLBCL } \\
\text { Ineligible for ASCT }\end{array}$ & $\begin{array}{c}19 \% \\
\S\end{array}$ & $44 \%$ & $0 \%$ & $\begin{array}{c}\text { ORR } 58 \% \\
\text { CR } 33 \% \\
\text { mOS } 22 \text { mos }\end{array}$ \\
\hline
\end{tabular}

FDA: United States Food and Drug Administration; Flu/Cy: Fludarabine/Cyclophosphamide; LD: lymphodepletion; Benda/Flu: Bendamustin/Cyclophosphamide; Pola: Polatuzumab vedotin; BR: Bendamustin and Rituximab; Ritux: Rituximab; LEN: Lenalidomide; Tafa: Tafasitamab; dx: diagnosis; DHL: Double Hit Lymphoma; THL: Triple Hit Lymphoma; R/R DLBCL: Relapsed or Refractory Diffuse Large B Cell Lymphoma; ORR: Overall Response Rate; CR: Complete Response; mOS: Median Overall Survival; mos: months; CMR: Complete Metabolic Response; po: by mouth; NR: Not Reported. a : investigational agent with pending Food and Drug Administration approval. § Excluded if received anti-CD20 therapy within 6 months. $\S \S$ Excluded if not in PR or CR and received therapy within 14 weeks. 


\section{Tafasitamab}

Tafasitamab (MOR208) is an Fc-enhanced, humanized, anti-CD19 monoclonal antibody that has shown preclinical and single-agent activity in patients with relapsed or refractory B-cell malignancies [23]. It has been engineered to have better antibody directed cellular cytotoxicity (ADCC) than a native antibody LEN enhances natural killer cell-meditated, antibody-dependent cellular cytotoxicity with tafasitamab in vitro [24]. A recently published analysis confirmed synergistic effects of combining tafasitamab with LEN by comparing the L-MIND study (combination) to RE-MIND (LEN monotherapy) [25]. L-MIND is an open-label, single-arm, phase II clinical trial of tafasitamab plus lenalidomide in patients with relapsed or refractory DLBCL who were ineligible for high-dose chemotherapy with autologous stem-cell transplantation due to factors such as advanced age, refusal, or comorbidities [22]. Double-hit (simultaneous detection of MYC with BCL2 or BCL6 translocation) and primary refractory patients who relapsed within 6 months of anti-CD20 therapy were excluded (in the first 6 months of recruitment the exclusion was only 3 months to be primary refractory). Of the 80 patients who received the dual therapy, $43 \%$ experienced complete responses and $18 \%$ exhibited partial responses, and the median duration of these responses was 21.7 months, which is in contrast to LEN monotherapy in similar patients, where only $13.2 \%$ experienced complete response [25], and in contrast to the R2 regimen of LEN and Rituximab for R/R DLBCL, where only $13.3 \%$ experienced complete response [26]. All Tafasitamab+LEN patients experienced treatment-emergent adverse events, with neutropenia being the most common adverse event. Nonhematologic adverse events were most often grade 1 or 2 and included diarrhea and rash [22]. Notably, 12\% of patients discontinued study treatment because of adverse events, and four patients died of treatment-emergent adverse events, although none of these deaths were deemed by the investigators to be due to the study treatment [27]. However, cytopenias are likely related to LEN use. Now in a phase $1 \mathrm{~b}$ study, MOR 208 is being studied in combination with R-CHOP and lenalidomide for frontline DLBCL treatment.

\section{Polatuzumab Vedotin}

Polatuzumab vedotin is an antibody-drug conjugate (ADC) consisting of a humanized anti-CD79b monoclonal antibody and the anti-mitotic agent, mono-methyl auristatin E (MMAE) [28]. This Polatuzumab vedotin's antibody recognizes the CD79b protein that is associated with the B-cell receptor. After the antibody binds to CD79b, the ADC's toxic payload (MMAE) enters the B cell and then kills it by preventing tubulin polymerization. Targeting the pan-B marker CD79b is ideal since it will not select for resistance to CD19 regimens for patients who may later require CAR T cell therapy directed against CD19 [29]. Given as a parenteral triplet, polatuzumab-vedotin plus bendamustine and rituximab is approved for third-line therapy use after demonstrating a median overall survival of 12.4 months compared with 4.7 months for patients receiving a current standard salvage regimen of bendamustine and ritixumab [20]. Patients were excluded if they had a history of grade $\geq 2$ peripheral neuropathy or prior HSCT. Primary-refractory nor double/triple-hit lymphomas were excluded. Adverse reactions led to dose reduction in $18 \%$, dose interruption in $51 \%$, and permanent discontinuation of all treatment in $31 \%$. The most common adverse reactions leading to treatment discontinuation were thrombocytopenia and/or neutropenia [30]. In early phase studies and clinical practice, experts suggest Polatuzumab has significant single agent activity and it can be given without bendamustine. The POLARGO study is a currently enrolling a multicenter phase III randomized controlled trial of pola-R-GemOx vs. R-GemOx alone in R/R DLBCL [31]. In patients with relapsed disease who need a bridge to either CAR-T or ASCT, polatuzumab has proven to be an active regimen used in this situation. Since polatuzumab has been effective and well tolerated, there is a currently ongoing trial, POLARIX, using it in upfront therapy with RCHOP. 


\section{Selinexor}

Selinexor, an oral selective inhibitor of XPO1-mediated nuclear export (SINE), has a broad potential mechanism of action. It induces the expected nuclear accumulation and activation of tumor suppressor proteins and reduces $\mathrm{Bcl} 2, \mathrm{Bcl}-\mathrm{X}_{\mathrm{L}}$, and $\mathrm{c}-\mathrm{Myc}$ oncoprotein concentrations [21]. It received accelerated FDA approval in 2019 for relapsed or refractory DLBCL after 2 lines of systemic therapy in addition to approval for relapsed Multiple Myeloma [32]. In the multicenter, open-label, phase 2b SADAL study, 127 patients with DLBCL who had received two to five lines of previous therapies, and progressed after or were not candidates for autologous stem-cell transplantation were given selinexor orally at the fixed dose of $60 \mathrm{mg}$ on day 1 and day 3 weekly, until disease progression or manifested unacceptable toxicity [33]. The primary endpoint of overall response rate was $28 \%(36 / 127)$ with median duration of response 23 months. Complete response was achieved in $12 \%$ with a median duration of 23.0 months. In the subgroup analysis of those with low c-myc expression by immunohistochemistry, the overall response rate was $42 \%$ [21]. Selinexor caused adverse events that were reversible with standard supportive care and dose modification to $40 \mathrm{mg}$ dosing. Without apparent cumulative toxicity, there is currently no maximum duration of treatment; the longest duration of treatment in the SADAL study with selinexor is $>3.5$ years [21]. Two experimental studies (NCT02303392 and NCT03955783) in aggressive lymphoma, testing the combinations of selinexor with ibrutinib or venetoclax are active and recruiting. Results of the studies might clarify if a totally oral and chemotherapy free treatment should be an option for patients with relapsed or refractory DLBCL.

\section{CAR T Cells}

Anti-CD19 CAR T cell therapy has transformed the approach to multiple-relapsed/refractory aggressive B-cell lymphomas. Three anti-CD19 CAR T cell products have demonstrated efficacy in relapsed DLBCL with a remarkably long duration of effect in patients who achieve a complete response. Second generation receptors, dual target CD19/CD22, novel dose escalation protocols, and addition of PD-1 blockade are in ongoing studies for improved efficacy and/or reduced toxicity [34]. The indications for use may expand in the future as the collection and manufacturing process becomes more streamlined and more centers develop experience managing its toxicities [9,35-37]. Currently, axicabtagene ciloleucel (axi-cel) and Tisagenlecleucel (tisa-cel) are approved by the US Food and Drug Administration in adults with relapsed or refractory DLBCL after two or more lines of systemic therapy. The ZUMA study $(n=101)$ of axi-cel reported a $58 \%$ CR and 24 month survival rate of $50.5 \%$. The cohort of patients age $\geq 65$ years $(n=81)$ had a $44 \%$ rate of grade $\geq 3$ neurologic toxicity. The JULIET study $(n=93)$ of tisagenlecleucel had a $40 \%$ CR and 12 month overall survival rate of $49 \%$. The TRANSCEND study $(n=344)$ of lisocabtagene maraleucel reported CR $53 \%$ and estimated 12 month overall survival rate $58 \%$, and only $1 \%$ experienced grade 3 or higher neurologic toxicity of confusional state during therapy [38]. Multiple randomized trials are currently enrolling patients with primary refractory or early relapsed aggressive B-cell lymphomas comparing anti-CD19 CAR T cell therapy with traditional salvage therapy and ASCT (TRANSFORM, NCT03575351; BELINDA, NCT03570892; and ZUMA-7, NCT03391466) [39]. A key limitation of CAR-T therapies is limitations in access and the time that lapses between collecting and infusing cells that ranged 17 to 54 days during phase 2 clinical trials [40].

\section{Sequencing Therapy}

With recent new drug approvals, treatment options for patients with R/R DLBCL have expanded. However, this poses a challenge in sequencing and treatment selection for patients. At this time, the sequencing of therapy is individualized based on the efficacy and side effect profile of treatment. In patients with R/R DLBCL, the treatment should be divided among transplant eligible and ineligible patients. If they are transplant ineligible or progress after ASCT, they have all the above approved regimens available as option. ASCT ineligible patients should be evaluated for CAR-T therapy as it 
offers the best ORR among therapies mentioned in Table 1. However, CAR-T can be challenging in terms of accessibility, the patient's functional status, disease burden and other factors. Polatuxumab Vedotin in combination with bendamustine and rituximab is another option and can be used as a bridge to CAR-T as well. Polatuzumab Veodtin in combination with BR had $40 \%$ of CRR and manageable toxicities [20]. If patients respond well, Bendamustine can be dropped to allow cell collection for CAR-T. However, it is a three drug regimen and it carries risk of grade 3 or 4 cytopenias and peripheral neuropathy. In patients that are not candidates for CAR-T and goal is palliation, Tafasitamab with lenalidomide is a great option with limited toxicities. Based on the L-Mind study, Tafasitamab + Len had ORR of $60 \%$ and CRR of $42.5 \%$ and main side effects were cytopenias managed by dose adjustment of lenalidomide [22]. Tafasitamab prior to CAR-T may alter efficacy of CAR-T therapy since they both are CD-19 targeted therapy; however, more data are needed to support this. Selinexor is another option for ASCT ineligible patients with ORR of $28 \%$; relatively lower than other agents. Selinexor also has a significant side effect profile for GI toxicity, hyponatremia and cytopenia, hence would reserve this as a last option.

\section{Future of DLBCL and Immunotherapy}

There are many other immunotherapy based regimens under early clinical trials aside from those mentioned above (Table 2).

Table 2. Novel Regimens under Investigation for Relapsed or Refractory Diffuse Large B Cell Lymphoma.

\begin{tabular}{|c|c|c|c|c|}
\hline \multicolumn{5}{|c|}{ Bispecific Abs } \\
\hline $\begin{array}{l}\text { Epcoritamab (CD3/CD20) } \\
\text { Flat dose } \\
\text { Subcutaneous weekly } \\
\text { Escalation study }\end{array}$ & $\begin{array}{l}\text { Hutchings et al. [41] } \\
\quad \text { NCT03625037 }\end{array}$ & $\begin{array}{l}\text { Phase } 1 / 2 \\
\text { R/R DLBCL }\end{array}$ & $N=41$ & $\begin{array}{c}\text { Enrolling } \\
\text { Median } \mathrm{f} / \mathrm{u} 4.7 \text { mo } \\
\text { ORR } 56 \% \\
\text { CR } 44 \% \\
\text { No dose limiting toxicities }\end{array}$ \\
\hline $\begin{array}{l}\text { Odronextamab } \\
\text { REGN1979 } \\
\text { (CD3/CD20) } \\
18-320 \text { mg doses }\end{array}$ & $\begin{array}{l}\text { Bannerji et al. [42] } \\
\text { NCT03888105 }\end{array}$ & $\begin{array}{c}\text { Phase } 1 \\
\text { R/R DLBCL }\end{array}$ & $N=19$ & $\begin{array}{l}\text { Enrolling phase } 2 \\
\text { ORR } 58 \% \\
\text { CR } 37 \%\end{array}$ \\
\hline $\begin{array}{l}\text { Monsenetuzumab } \\
\text { (CD3/CD20) }\end{array}$ & $\begin{array}{l}\text { Schuster et al. [43] } \\
\text { NCT03677154 }\end{array}$ & $\begin{array}{c}\text { Phase } 1 / 2 \\
\text { R/R DLBCL including } \\
\text { p CAR-T }\end{array}$ & $N=119$ & $\begin{array}{l}\text { Enrolling phase } 3 \\
\text { ORR } 34.7 \% \\
\text { CR } 18.6 \%\end{array}$ \\
\hline $\begin{array}{l}\text { Glofitamab } \\
\text { RG6026 } \\
\text { (CD3/CD20) }\end{array}$ & $\begin{array}{l}\text { Morschhauser et al. [44] } \\
\text { NCT03075696 }\end{array}$ & $\begin{array}{c}\text { Phase } 1 / \mathrm{Ib} \\
\mathrm{R} / \mathrm{R} \text { aggressive } \mathrm{NHL} \\
+/- \text { Obinituzumab }\end{array}$ & $N=21$ & $\begin{array}{c}\text { Enrolling Phase } 1 \\
\text { ORR } 38 \% \\
\text { CR } 31 \%\end{array}$ \\
\hline \multicolumn{5}{|c|}{ Monoclonal Abs } \\
\hline $\begin{array}{l}\text { Tafasitamab (anti-CD19) } \\
\text { (Fc-enhanced, humanized) } \\
\text { +Lenolidomide }\end{array}$ & $\begin{array}{l}\text { Nowakowski et al. [25] } \\
\text { Maddocks et al. [45] } \\
\text { NCT02399085 }\end{array}$ & $\begin{array}{c}\text { Phase } 1 / 2 \\
\text { R/R DLBCL } \\
\text { Ineligible for ASCT } \\
\text { Excluded double-hit }\end{array}$ & $N=81$ & $\begin{array}{l}\text { Enrolling phase } 3 \\
\text { ORR } 58 \% \\
\text { CR } 33 \% \\
\text { Median OS } 22 \text { mos } \\
\text { (95\% CI: } 18.6-\mathrm{NR}) \\
\end{array}$ \\
\hline $\begin{array}{c}\text { Magrolimab }(5 \mathrm{~F} 9) \\
\text { (anti-CD47, promote phagocytosis) } \\
\text { + Rituximab }\end{array}$ & $\begin{array}{l}\text { Advani et al. [46] } \\
\text { NCT02953509 }\end{array}$ & $\begin{array}{l}\text { Phase } 1 \mathrm{~b} / 2 \\
\text { R/R DLBCL }\end{array}$ & $N=15$ & $\begin{array}{c}\text { Enrolling, Preliminary results } \\
\text { ORR } 40 \% \\
\text { CR } 27 \% \\
\text { On-target anemia } \\
\text { primarily 1st dose }\end{array}$ \\
\hline \multicolumn{5}{|c|}{ Anti-PD-L1 Containing Regimens } \\
\hline $\begin{array}{l}\text { Atezolizumab } \\
\text { (anti-PDL1) } \\
\text { +Obinituzumab } \\
\quad \text { (anti-CD20) } \\
\text { +Venetoclax } \\
\text { (BCL2 inhibitor) }\end{array}$ & $\begin{array}{l}\text { Herbaux et al. [47] } \\
\text { NCT03276468 }\end{array}$ & $\begin{array}{l}\text { Phase } 2 \\
\text { R/R DLBCL }\end{array}$ & $N=58$ & $\begin{array}{l}\text { Interim Results } \\
\text { ORR } 23.6 \% \\
\text { CMR } 18 \%\end{array}$ \\
\hline $\begin{array}{l}\text { Mogamulizumab } \\
\quad \text { (anti-CCR4) } \\
+ \text { Pembrolizumab }\end{array}$ & $\begin{array}{c}\text { Joffe et al. } \\
\text { NCT03309878 }\end{array}$ & $\begin{array}{c}\text { Phase } 1 \mathrm{~b} / 2 \\
\mathrm{R} / \mathrm{R} \text { DLBCL } \\
\text { Ineligible for ASCT }\end{array}$ & & Enrolling \\
\hline $\begin{array}{c}\text { Avelumab (anti-PD-L1) } \\
\text { +/- Utomilumab } \\
\text { (4-1BB agonist) } \\
\text { +/- Rituximab } \\
\text { +/- Bendamustine or Azacitidine }\end{array}$ & $\begin{array}{l}\text { Chen et al. [48] } \\
\text { NCT02951156 }\end{array}$ & $\begin{array}{c}\text { Phase } 1 \mathrm{~b} / 3 \\
\text { R/R DLBCL } \\
\text { Ineligible for ASCT } \\
\text { ECOG } \leq 1\end{array}$ & & Enrolling \\
\hline
\end{tabular}


Table 2. Cont.

\begin{tabular}{|c|c|c|c|c|}
\hline \multicolumn{5}{|c|}{ Bispecific CAR T Cell Therapies } \\
\hline $\begin{array}{l}\text { AUTO3 }(\mathrm{CD} 19 / \mathrm{CD} 22) \\
\text { Dual targeted } \\
\text { +Pembrolizumab }\end{array}$ & $\begin{array}{l}\text { Osborne et al. } \\
\text { NCT03287817 }\end{array}$ & $\begin{array}{l}\text { Phase } 1 / 2 \\
\text { R/R DLBCL }\end{array}$ & $N=11$ & ORR 64\%CRR 55\% \\
\hline $\begin{array}{l}\text { LV20.19CAR (CD19/CD20) } \\
\text { Dual targeted } \\
\text { Lentiviral }\end{array}$ & $\begin{array}{l}\text { Shah et al. [49] } \\
\text { NCT03019055 }\end{array}$ & $\begin{array}{c}\text { Phase } 1 \\
\text { R/R NHL } \\
45 \% \text { DLBCL }\end{array}$ & & $\begin{array}{c}\text { Enrolling in expansion phase } \\
\text { ORR } 82 \% \\
\text { CR } 54.5 \% \\
\text { No grade } 3-4 \text { CRS or NTX in } \\
\text { first } 11 \text { pts. }\end{array}$ \\
\hline \multicolumn{5}{|c|}{ Antibody-Drug Conjugates } \\
\hline $\begin{array}{l}\text { Polatuzumab vedotin } \\
\text { (anti-CD79b/MMAE) added to BR }\end{array}$ & $\begin{array}{l}\text { Sehn et al. [20] } \\
\text { Lu et al. [28] } \\
\text { NCT02257567 } \\
\end{array}$ & $\begin{array}{c}\text { Phase } 2 \\
\text { R/R DLBCL } \\
\text { Ineligible for ASCT }\end{array}$ & $N=80$ & $\begin{array}{c}\text { CMR } 40 \% \\
\text { Median OS } 12.4 \text { mos }\end{array}$ \\
\hline $\begin{array}{l}\text { Polatuzumab vedotin } \\
\text { (anti-CD79b/MMAE) added to Gem-Ox }\end{array}$ & $\begin{array}{l}\text { Haioun et al. [31] } \\
\text { NCT04182204 }\end{array}$ & $\begin{array}{l}\text { Phase } 3 \\
\text { R/R DLBCL }\end{array}$ & & Enrolling \\
\hline \multicolumn{5}{|c|}{ Engineered Toxin Bodies } \\
\hline $\begin{array}{l}\text { MT-3724 (CD20/ } \\
\text { SLT-I A1) }\end{array}$ & $\begin{array}{l}\text { Fanale et al. [50] } \\
\text { Duque et al. [51] } \\
\text { NCT02361346 }\end{array}$ & $\begin{array}{l}\text { Phase } 1 \\
\text { Relapsed B-NHL after } \\
\text { anti-CD20 and CT }\end{array}$ & $N=100$ & $\begin{array}{l}\text { Safety and efficacy assessment } \\
\text { of } 50 \mathrm{mcg} / \mathrm{kg} / \text { dose ongoing. }\end{array}$ \\
\hline \multicolumn{5}{|c|}{ PI3K Inhibitor } \\
\hline $\begin{array}{l}\text { Parsaclisib } 20 \mathrm{mg} \\
\quad \text { po daily }\end{array}$ & $\begin{array}{l}\text { Coleman et al. [52,53] } \\
\text { NCT02998476 }\end{array}$ & $\begin{array}{l}\text { Phase } 2 \\
\text { R/R DLBCL }\end{array}$ & $N=60$ & $\begin{array}{c}\text { Interim Results } \\
\text { ORR } 25 \% \\
\text { CMR } 12.5 \% \\
\end{array}$ \\
\hline $\begin{array}{l}\text { Buparlisib } 80 \mathrm{mg} \\
\text { po daily } \\
\text { +Ibrutinib }\end{array}$ & $\begin{array}{l}\text { Batlevi et al. [54] } \\
\text { NCT02756247 }\end{array}$ & $\begin{array}{l}\text { Phase } 1 / 2 \\
\text { R/R DLBCL, Mantle } \\
\text { Cell, Follicular }\end{array}$ & $N=37$ & $\begin{array}{l}\text { Interim Results } \\
\text { ORR } 31 \% \\
\text { CMR } 23 \%\end{array}$ \\
\hline \multicolumn{5}{|c|}{ BTK Inhibitors } \\
\hline $\begin{array}{l}\text { Acalabrutinib } 100 \mathrm{mg} \\
\text { po BID } \\
+ \text { Pembrolizumab }\end{array}$ & $\begin{array}{l}\text { Witzig et al. [55] } \\
\text { NCT02362035 }\end{array}$ & $\begin{array}{l}\text { Phase } 1 / 2 \\
\text { R/R DLBCL }\end{array}$ & $N=61$ & $\begin{array}{l}\text { ORR } 26 \% \\
\text { CR } 7 \%\end{array}$ \\
\hline Zanubrutinib 160 mg po BID & $\begin{array}{l}\text { Yang et al. [56] } \\
\text { NCT03145064 }\end{array}$ & $\begin{array}{c}\text { Phase } 2 \\
\text { R/R Non-GBC DLBCL } \\
\text { Ineligible for ASCT }\end{array}$ & $N=41$ & $\begin{array}{c}\text { ORR } 29.3 \% \\
\text { CR } 17.1 \% \\
\text { Median OS } 8.4 \mathrm{mos}\end{array}$ \\
\hline \multicolumn{5}{|c|}{ Immunomodulators } \\
\hline $\begin{array}{c}\text { R2-GDP } \\
\text { Lenalidomide } 10 \mathrm{mg} \text { po d1-14 + R-GDP }\end{array}$ & $\begin{array}{l}\text { Merino et al. [57] } \\
\text { EudraCT 2014-001620-29 }\end{array}$ & $\begin{array}{c}\text { Phase } 2 \\
\text { R/R DLBCL } \\
\text { Ineligible for ASCT }\end{array}$ & $N=79$ & $\begin{array}{c}\text { Enrolling } \\
\text { ORR } 59 \% \\
\text { CR } 32 \% \\
\text { Median OS } 12 \mathrm{mos}\end{array}$ \\
\hline $\begin{array}{c}\text { R2-ICE } \\
\text { Lenalidomide } 20 \text { mg po d1-14 + RICE }\end{array}$ & $\begin{array}{l}\text { Guerra-Bauman et al. } \\
\text { [58] } \\
\text { NCT02628405 }\end{array}$ & $\begin{array}{c}\text { Phase } 1 / 2 \\
\text { R/R DLBCL } \\
\text { Candidates for ASCT }\end{array}$ & & Enrolling \\
\hline
\end{tabular}

$\overline{\mathrm{PO}}=$ by mouth; $\mathrm{BID}=$ twice daily; $\mathrm{Mo}(\mathrm{s})=$ month(s); ORR = Overall Response Rate; $\mathrm{CR}=$ Complete Response; $\mathrm{CMR}=$ Complete Metabolic Response by Positron Emission Testing (PET); CT = Chemotherapy; $\mathrm{BR}=$ Bendamustin/Rituximab; Gem-Ox = Gemcitabine/Oxaliplatin; AE Trmt DC Ac/Pem = Adverse Events causing Treatment Discontinuation due to Acalabrutinib/Pembrolizumab; SLT-I A1 = Shiga-like toxin-I A1; R2-GDP (Lenalidomide, Rituximab, Gemcitabine, Dexamethasone, Cisplatin); R2-ICE (Lenalidomide, Rituximab, Ifosfamide, Carboplatin, Etoposide).

MT-3724 is a novel Engineered Toxic Body (ETB) comprised of a proprietarily engineered form of Shiga-like Toxin A subunit (SLT-A) genetically fused to an antibody-like binding domain that binds CD20. ETBs work though a novel mechanism of action whereby the internalization of the fragment when bound to CD20 delivers the toxin intracellularly where ribosomal inactivation leads to targeted cell death [50,51]. MT-3724 is currently being studied in three ongoing Phase 2 studies for relapsed and refractory DLBCL. Loncastuximab tesirine, ADCT-402 is an antibody-drug conjugate composed of a humanized monoclonal antibody against CD19 and conjugated to a pyrrolobenzodiazepine dimer cytotoxin. In phase 2 trials, ADCT-402, 145 pts with relapsed or refractory DLBCL were enrolled and ORR was $45 \%$. The common side effects were cytopenias requiring dose adjustments, which were otherwise well tolerated. Hu5F9-G4, a humanized monoclonal antibody is a macrophage immune checkpoint inhibitor blocking CD47 that induces tumor-cell phagocytosis. A phase 1B study, $22 \mathrm{pts}$ with relapsed NHL were treated with Hu5F9-G4 in combination with rituximab. The ORR in DLBCL subset was $40 \%$ with CR of $33 \%$. The most common AEs were infusion reaction, fever and chills. Immune checkpoint inhibitors have gained recognition in multiple solid tumors and demonstrated durable responses. PD-1 and PDL-1 are expressed in many hematologic malignancies and have recently been approved for second line HL. In a phase 1 trial of relapsed DLBCL patients, nivolumab 
showed an ORR of $36 \%$, but these responses were not durable. There are a few trials in DLBCL being completed with immune checkpoint inhibitors in combination with anti-CD-20 antibodies (NCT03401853) and immunomodulators and targeted agents such as LEN (NCT03015896) and Copanlisib (NCT03484819). Table 1 includes a list early clinical trials involving immunotherapy for treatment of relapsed/refractory DLBCL.

\section{Conclusions}

Novel agents are changing treatment strategies in relapsed or refractory DLBCL after the failure of cytotoxic chemoimmunotherapy. Harnessing the surveillance of the patient's T cell immunity has produced prolonged responses in studies of heavily pre-treated patients. The inclusion of immunotherapies such as CAR T cells, bispecific antibodies, ADCs, and other immunomodulatory drugs to the treatment algorithms for DLBCL is filling the unmet need for agents with activity in the multiply relapsed setting. A recurring theme in the development of noncytotoxic regimens is that chemotherapy free does not equal toxicity-free [39]. Distinct adverse effects seen with immunotherapies are part of these treatment decisions, and ongoing studies are informing the physical toxicities expected in broader populations. Learning which patients reap the most benefit from these agents enables more accurate calculations of financial toxicities.

Author Contributions: Conceptualization, K.P. and M.M.; Writing-Original draft preparation, L.J.H.; Writing-Review and editing, L.J.H., K.P., M.M.; supervision, M.M. All authors have read and agreed to the published version of the manuscript.

Funding: This research received no external funding.

Conflicts of Interest: The authors declare no conflict of interest.

\section{References}

1. Swerdlow, S.H.; Campo, E.; Pileri, S.A.; Harris, N.L.; Stein, H.; Siebert, R.; Advani, R.; Ghielmini, M.; Salles, G.A.; Zelenetz, A.D.; et al. The 2016 revision of the World Health Organization classification of lymphoid neoplasms. Blood 2016, 127, 2375-2390. [CrossRef] [PubMed]

2. Tkacz, J.; Garcia, J.; Gitlin, M.; McMorrow, D.; Snyder, S.; Bonafede, M.; Chung, K.C.; Maziarz, R.T. The economic burden to payers of patients with diffuse large B-cell lymphoma during the treatment period by line of therapy. Leuk. Lymphoma 2020, 61, 1601-1609. [CrossRef] [PubMed]

3. Grimm, K.E.; O'Malley, D.P. Aggressive B cell lymphomas in the 2017 revised WHO classification of tumors of hematopoietic and lymphoid tissues. Ann. Diagn. Pathol. 2019, 38, 6-10. [CrossRef] [PubMed]

4. Hu, S.; Xu-Monette, Z.Y.; Tzankov, A.; Green, T.; Wu, L.; Balasubramanyam, A.; Liu, W.M.; Visco, C.; Li, Y.; Miranda, R.N.; et al. MYC/BCL2 protein coexpression contributes to the inferior survival of activated B-cell subtype of diffuse large B-cell lymphoma and demonstrates high-risk gene expression signatures: A report from The International DLBCL Rituximab-CHOP Consortium Program. Blood 2013, 121, 4021-4031. [CrossRef]

5. Dunleavy, K.; Fanale, M.A.; Abramson, J.S.; Noy, A.; Caimi, P.F.; Pittaluga, S.; Parekh, S.; Lacasce, A.; Hayslip, J.W.; Jagadeesh, D.; et al. Dose-adjusted EPOCH-R (etoposide, prednisone, vincristine, cyclophosphamide, doxorubicin, and rituximab) in untreated aggressive diffuse large B-cell lymphoma with MYC rearrangement: A prospective, multicentre, single-arm phase 2 study. Lancet Haematol. 2018, 5, e609-e617. [CrossRef]

6. Ziepert, M.; Hasenclever, D.; Kuhnt, E.; Glass, B.; Schmitz, N.; Pfreundschuh, M.; Loeffler, M. Standard International prognostic index remains a valid predictor of outcome for patients with aggressive CD20+ B-cell lymphoma in the rituximab era. J. Clin. Oncol. 2010, 28, 2373-2380. [CrossRef]

7. Chapuy, B.; Stewart, C.; Dunford, A.J.; Kim, J.; Kamburov, A.; Redd, R.A.; Lawrence, M.S.; Roemer, M.G.M.; Li, A.J.; Ziepert, M.; et al. Molecular subtypes of diffuse large B cell lymphoma are associated with distinct pathogenic mechanisms and outcomes. Nat. Med. 2018, 24, 679-690. [CrossRef] 
8. Van Den Neste, E.; Schmitz, N.; Mounier, N.; Gill, D.; Linch, D.; Trneny, M.; Milpied, N.; Radford, J.; Ketterer, N.; Shpilberg, O; et al. Outcome of patients with relapsed diffuse large B-cell lymphoma who fail second-line salvage regimens in the International CORAL study. Bone Marrow Transpl. 2016, 51, 51-57. [CrossRef]

9. Schuster, S.J.; Bishop, M.R.; Tam, C.S.; Waller, E.K.; Borchmann, P.; McGuirk, J.P.; Jager, U.; Jaglowski, S.; Andreadis, C.; Westin, J.R.; et al. Tisagenlecleucel in Adult Relapsed or Refractory Diffuse Large B-Cell Lymphoma. N. Engl. J. Med. 2019, 380, 45-56. [CrossRef]

10. Gisselbrecht, C.; Glass, B.; Mounier, N.; Singh Gill, D.; Linch, D.C.; Trneny, M.; Bosly, A.; Ketterer, N.; Shpilberg, O.; Hagberg, H.; et al. Salvage regimens with autologous transplantation for relapsed large B-cell lymphoma in the rituximab era. J. Clin. Oncol. 2010, 28, 4184-4190. [CrossRef]

11. Crump, M. Management of Relapsed Diffuse Large B-cell Lymphoma. Hematol. Oncol. Clin. N. Am. 2016, 30, 1195-1213. [CrossRef] [PubMed]

12. Crump, M.; Kuruvilla, J.; Couban, S.; MacDonald, D.A.; Kukreti, V.; Kouroukis, C.T.; Rubinger, M.; Buckstein, R.; Imrie, K.R.; Federico, M.; et al. Randomized comparison of gemcitabine, dexamethasone, and cisplatin versus dexamethasone, cytarabine, and cisplatin chemotherapy before autologous stem-cell transplantation for relapsed and refractory aggressive lymphomas: NCIC-CTG LY.12. J. Clin. Oncol. 2014, 32, 3490-3496. [CrossRef] [PubMed]

13. Ionescu-Ittu, R.; Shang, A.; Velde, N.V.; Guerin, A.; Lin, Y.; Shi, L.; Shi, S.; Qayum, N. Second-line rituximab-bendamustine versus rituximab-gemcitabine-oxaliplatin in diffuse large B-cell lymphoma in the real world. J. Comp. Eff. Res. 2019, 8, 1067-1075. [CrossRef] [PubMed]

14. Vosuri, V.; Kaisreddy, R.; Bandi, S. Comparison of salvage therapies for relapsed or refractory diffuse large B-cell lymphoma (DLBCL): Network meta-analysis. J. Clin. Oncol. 2019, 37. [CrossRef]

15. Nabhan, C.; Klink, A.; Lee, C.H.; Laney, J.R.; Yang, Y.; Purdum, A.G. Overall survival (OS) and transplantation (ASCT) utilization in real-world patients with relapsed/refractory diffuse large B-cell lymphoma (RR-DLBCL). J. Clin. Oncol. 2018, 36. [CrossRef]

16. Crump, M.; Neelapu, S.S.; Farooq, U.; Van Den Neste, E.; Kuruvilla, J.; Westin, J.; Link, B.K.; Hay, A.; Cerhan, J.R.; Zhu, L.; et al. Outcomes in refractory diffuse large B-cell lymphoma: Results from the international SCHOLAR-1 study. Blood 2017, 130, 1800-1808. [CrossRef]

17. Coyle, L.; Morley, N.J.; Rambaldi, A.; Mason, K.D.; Verhoef, G.; Furness, C.L.; Zhang, A.; Jung, A.S.; Cohan, D.; Franklin, J.L. Open-Label, phase 2 study of blinatumomab as second salvage therapy in adults with relapsed/refractory aggressive B-cell non-Hodgkin lymphoma. Leuk. Lymphoma 2020, 1-10. [CrossRef]

18. Purdum, A.; Tieu, R.; Reddy, S.R.; Broder, M.S. Direct Costs Associated with Relapsed Diffuse Large B-Cell Lymphoma Therapies. Oncologist 2019, 24, 1229-1236. [CrossRef]

19. Patel, K.K.; Isufi, I.; Kothari, S.; Foss, F.; Huntington, S. Cost-effectiveness of polatuzumab vedotin in relapsed or refractory diffuse large B-cell lymphoma. Leuk. Lymphoma 2020, 1-8. [CrossRef]

20. Sehn, L.H.; Herrera, A.F.; Flowers, C.R.; Kamdar, M.K.; McMillan, A.; Hertzberg, M.; Assouline, S.; Kim, T.M.; Kim, W.S.; Ozcan, M.; et al. Polatuzumab Vedotin in Relapsed or Refractory Diffuse Large B-Cell Lymphoma. J. Clin. Oncol. 2020, 38, 155-165. [CrossRef]

21. Kalakonda, N.; Maerevoet, M.; Cavallo, F.; Follows, G.; Goy, A.; Vermaat, J.S.P.; Casasnovas, O.; Hamad, N.; Zijlstra, J.M.; Bakhshi, S.; et al. Selinexor in patients with relapsed or refractory diffuse large B-cell lymphoma (SADAL): A single-arm, multinational, multicentre, open-label, phase 2 trial. Lancet Haematol. 2020, 7 , e511-e522. [CrossRef]

22. Salles, G.; Duell, J.; Gonzalez Barca, E.; Tournilhac, O.; Jurczak, W.; Liberati, A.M.; Nagy, Z.; Obr, A.; Gaidano, G.; Andre, M.; et al. Tafasitamab plus lenalidomide in relapsed or refractory diffuse large B-cell lymphoma (L-MIND): A multicentre, prospective, single-arm, phase 2 study. Lancet Oncol. 2020, 21, 978-988. [CrossRef]

23. Jurczak, W.; Zinzani, P.L.; Hess, G.; Gaidano, G.; Provencio, M.; Nagy, Z.; Robak, T.; Maddocks, K.J.; Buske, C.; Ambarkhane, S.; et al. A Phase IIa, Open-Label, Multicenter Study of Single-Agent Tafasitamab (MOR208), an Fc-Optimized Anti-CD19 Antibody, in Patients with Relapsed or Refractory B-Cell Non-Hodgkin's Lymphoma: Long-Term Follow-up, Final Analysis. Blood 2019, 134, 4078. [CrossRef]

24. Gribben, J.G.; Fowler, N.; Morschhauser, F. Mechanisms of Action of Lenalidomide in B-Cell Non-Hodgkin Lymphoma. J. Clin. Oncol. 2015, 33, 2803-2811. [CrossRef] [PubMed] 
25. Nowakowski, G.S.; Rodgers, T.D.; Marino, D.; Frezzato, M.; Barbui, A.M.; Castellino, C.; Meli, E.; Fowler, N.H.; Feinberg, B.A.; Tillmann, S.; et al. RE-MIND study: A propensity score-based 1:1 matched comparison of tafasitamab + lenalidomide (L-MIND) versus lenalidomide monotherapy (real-world data) in transplant-ineligible patients with relapsed/refractory (R/R) diffuse large B-cell lymphoma (DLBCL). J. Clin. Oncol. 2020, 38. [CrossRef]

26. Wang, M.; Fowler, N.; Wagner-Bartak, N.; Feng, L.; Romaguera, J.; Neelapu, S.S.; Hagemeister, F.; Fanale, M.; Oki, Y.; Pro, B.; et al. Oral lenalidomide with rituximab in relapsed or refractory diffuse large cell, follicular and transformed lymphoma: A phase II clinical trial. Leukemia 2013, 27, 1902-1909. [CrossRef]

27. Rose, S.C.; Catherine, C.; Lewis, D.L. Diffuse Large B-cell Lymphoma Responds to Tafasitamab plus Lenalidomide. Cancer Discov. 2020, 10, 1091. [CrossRef]

28. Lu, T.; Gibiansky, L.; Li, X.; Li, C.; Shi, R.; Agarwal, P.; Hirata, J.; Miles, D.; Chanu, P.; Girish, S.; et al. Exposure-safety and exposure-efficacy analyses of polatuzumab vedotin in patients with relapsed or refractory diffuse large B-cell lymphoma. Leuk. Lymphoma 2020, 1-10. [CrossRef]

29. Shingleton, J.R.; Dave, S.S. Polatuzumab Vedotin Approved for DLBCL. Cancer Discov. 2019, 9, OF2. [CrossRef]

30. Polavy FDA Prescriber Label. Available Online: https://www.accessdata.fda.gov/drugsatfda_docs/label/ 2019/761121s000lbl.pdf (accessed on 14 August 2020).

31. Haioun, C.; Matasar, M.J.; Sancho, J.-M.; Viardot, A.; Hernandez, J.; Perretti, T.; McMillan, A. POLARGO: Randomized Phase III study of polatuzumab vedotin plus rituximab, gemcitabine, and oxaliplatin (R-GemOx) in relapsed/refractory diffuse large B-cell lymphoma (R/R DLBCL). J. Clin. Oncol. 2020, 38. [CrossRef]

32. Jencks, S.F.; Williams, M.V.; Coleman, E.A. Rehospitalizations among Patients in the Medicare Fee-for-Service Program. N. Engl. J. Med. 2009, 360, 1418-1428. [CrossRef] [PubMed]

33. Chiappella, A.; Corradini, P. Selective inhibitors of nuclear export in aggressive B-cell lymphomas. Lancet Haematol. 2020, 7, e500-e501. [CrossRef]

34. Osborne, W.; Marzolini, M.; Tholouli, E.; Ramakrishnan, A.; Bachier, C.R.; McSweeney, P.A.; Irvine, D.; Zhang, M.; Al-Hajj, M.A.; Pule, M.; et al. Phase I Alexander study of AUTO3, the first CD19/22 dual targeting CAR T cell therapy, with pembrolizumab in patients with relapsed/refractory (r/r) DLBCL. J. Clin. Oncol. 2020, 38. [CrossRef]

35. Chavez, J.C.; Bachmeier, C.; Kharfan-Dabaja, M.A. CAR T-cell therapy for B-cell lymphomas: Clinical trial results of available products. Adv. Hematol. 2019, 10, 2040620719841581. [CrossRef] [PubMed]

36. Locke, F.L.; Ghobadi, A.; Jacobson, C.A.; Miklos, D.B.; Lekakis, L.J.; Oluwole, O.O.; Lin, Y.; Braunschweig, I.; Hill, B.T.; Timmerman, J.M.; et al. Long-term safety and activity of axicabtagene ciloleucel in refractory large B-cell lymphoma (ZUMA-1): A single-arm, multicentre, phase 1-2 trial. Lancet Oncol. 2019, 20, 31-42. [CrossRef]

37. Fitzgerald, L.; Kittai, A.; Nastoupil, L.J.; Waller, A.; Jacobson, C.A.; Saucier, A.; Kamdar, M.K.; Spradley, J.; Denlinger, N.; Chipman, J.; et al. Real-world outcomes of elderly patients with relapsed/refractory (R/R) diffuse large B-cell lymphoma (DLBCL) treated with chimeric antigen receptor T-cell (CAR-T) therapy. J. Clin. Oncol. 2020, 38. [CrossRef]

38. Roex, G.; Feys, T.; Beguin, Y.; Kerre, T.; Poire, X.; Lewalle, P.; Vandenberghe, P.; Bron, D.; Anguille, S. Chimeric Antigen Receptor-T-Cell Therapy for B-Cell Hematological Malignancies: An Update of the Pivotal Clinical Trial Data. Pharmaceutics 2020, 12, 194. [CrossRef]

39. Abramson, J.S.; Ghosh, N.; Smith, S.M. ADCs, BiTEs, CARs, and Small Molecules: A New Era of Targeted Therapy in Non-Hodgkin Lymphoma. Am. Soc. Clin. Oncol. Educ. Book 2020, 40, 302-313. [CrossRef]

40. Neelapu, S.S.; Locke, F.L.; Bartlett, N.L.; Lekakis, L.J.; Miklos, D.B.; Jacobson, C.A.; Braunschweig, I.; Oluwole, O.O.; Siddiqi, T.; Lin, Y.; et al. Axicabtagene Ciloleucel CAR T-Cell Therapy in Refractory Large B-Cell Lymphoma. N. Engl. J. Med. 2017, 377, 2531-2544. [CrossRef]

41. Hutchings, M.; Lugtenburg, P.; Mous, R.; Clausen, M.R.; Chamuleau, M.; Linton, K.; Rule, S.; Lopez, J.S.; Oliveri, R.S.; DeMarco, D.; et al. Epcoritamab (GEN3013; DuoBody-CD3×CD20) to induce complete response in patients with relapsed/refractory B-cell non-Hodgkin lymphoma (B-NHL): Complete dose escalation data and efficacy results from a phase I/II trial. J. Clin. Oncol. 2020, 38. [CrossRef] 
42. Bannerji, R.; Allan, J.N.; Arnason, J.E.; Brown, J.R.; Advani, R.H.; Barnes, J.A.; Ansell, S.M.; O'Brien, S.M.; Chavez, J.; Duell, J.; et al. Clinical Activity of REGN1979, a Bispecific Human, Anti-CD20 x Anti-CD3 Antibody, in Patients with Relapsed/Refractory (R/R) B-Cell Non-Hodgkin Lymphoma (B-NHL). Blood 2019, 134, 762. [CrossRef]

43. Schuster, S.J.; Bartlett, N.L.; Assouline, S.; Yoon, S.-S.; Bosch, F.; Sehn, L.H.; Cheah, C.Y.; Shadman, M.; Gregory, G.P.; Ku, M.; et al. Mosunetuzumab Induces Complete Remissions in Poor Prognosis Non-Hodgkin Lymphoma Patients, Including Those Who Are Resistant to or Relapsing After Chimeric Antigen Receptor T-Cell (CAR-T) Therapies, and Is Active in Treatment through Multiple Lines. Blood 2019, 134, 6. [CrossRef]

44. Morschhauser, F.; Carlo-Stella, C.; Offner, F.; Salles, G.A.; Hutchings, M.; Iacoboni, G.; Sureda, A.; Crump, M.; Martinez-Lopez, J.; Thomas, D.; et al. Dual CD20-Targeted Therapy With Concurrent CD20-TCB and Obinutuzumab Shows Highly Promising Clinical Activity and Manageable Safety in Relapsed or Refractory B-Cell Non-Hodgkin Lymphoma: Preliminary Results From a Phase Ib Trial. Blood 2019, 134, 1584. [CrossRef]

45. Maddocks, K.J.; Duell, J.; Barca, E.G.; Jurczak, W.; Liberati, A.M.; Nagy, Z.; Obr, A.; Gaidano, G.; André, M.; Kalakonda, N.; et al. Update of the single-arm phase II L-MIND study of MOR208 + lenalidomide (LEN) in relapsed/refractory diffuse large B-cell lymphoma (R-R DLBCL): Response rates in patient subgroups with poor prognosis. J. Clin. Oncol. 2019, 37. [CrossRef]

46. Advani, R.H.; Flinn, I.; Popplewell, L.; Forero-Torres, A.; Bartlett, N.L.; Ghosh, N.; Kline, J.P.; Tran, T.; Lynn, J.; Chen, J.Y.; et al. Activity and tolerabilty of the first-in-class anti-CD47 antibody Hu5F9-G4 with rituximab tolerated in relapsed/refractory non-Hodgkin lymphoma: Initial phase 1b/2 results. J. Clin. Oncol. 2018, 36. [CrossRef]

47. Herbaux, C.; Casasnovas, O.; Feugier, P.; Damaj, G.; Bouabdallah, R.; Guidez, S.; Ysebaert, L.; Tilly, H.; Gouill, S.L.; Fornecker, L.; et al. Atezolizumab + obinutuzumab + venetoclax in patients with relapsed or refractory diffuse large B-cell Lymphomas (R/R DLBCL): Primary analysis of a phase II trial from LYSA. J. Clin. Oncol. 2020, 38. [CrossRef]

48. Chen, R.W.; Ansell, S.M.; Zinzani, P.L.; Vacirca, J.L.; Lopez-Guillermo, A.; Hutchings, M.; Jurczak, W.; Hess, G.; Gouill, S.L.; Offner, F.; et al. Phase 1b/3 study of avelumab-based combination regimens in patients with relapsed or refractory diffuse large B-cell lymphoma (R/R DLBCL). J. Clin. Oncol. 2017, 35. [CrossRef]

49. Shah, N.N.; Zhu, F.; Schneider, D.; Taylor, C.; Krueger, W.; Worden, A.; Longo, W.L.; Hamadani, M.; Fenske, T.; Johnson, B.; et al. Results of a phase I study of bispecific anti-CD19, anti-CD20 chimeric antigen receptor (CAR) modified T cells for relapsed, refractory, non-Hodgkin lymphoma. J. Clin. Oncol. 2019, 37. [CrossRef]

50. Fanale, M.A.; Hamlin, P.A.; Park, S.I.; Persky, D.O.; Higgins, J.P.; Burnett, C.; Dabovic, K.; Poma, E.; Sarapa, N.; Younes, A. Safety and efficacy of anti-CD20 immunotoxin MT-3724 in relapsed/refractory (R/R) B-cell non-Hodgkin lymphoma (NHL) in a phase I study. J. Clin. Oncol. 2018, 36, 7580. [CrossRef]

51. Duque, A.E.D.; Perekhrestenko, T.; Musteata, V.; Zodelava, M.; Guthrie, T.H.; Strack, T.; Burnett, C.; Wilson, S.; Waltzman, R.J.; Baetz, T.D.; et al. A phase II study of MT-3724, a novel CD20-targeting engineered toxin body, to evaluate safety, pharmacodynamics, and efficacy in subjects with relapsed or refractory diffuse large B-cell lymphoma. J. Clin. Oncol. 2020, 38. [CrossRef]

52. Coleman, M.; Belada, D.; Casasnovas, R.-O.; Gressin, R.; Lee, H.-P.; Mehta, A.; Munoz, J.; Verhoef, G.; Corrado, C.; DeMarini, D.J.; et al. Phase 2 study of parsaclisib (INCB050465) for relapsed or refractory diffuse large b-cell lymphoma (DLBCL) (CITADEL-202). J. Clin. Oncol. 2019, 37, e19038. [CrossRef]

53. Coleman, M.; Forero-Torres, A.; Ribrag, V.; Chau, I.; DeMarini, D.J.; Zinzani, P.L. Phase 2 study of the safety and efficacy of INCB050465 in patients with relapsed or refractory (R/R) diffuse large b-cell lymphoma (DLBCL) (CITADEL-202). J. Clin. Oncol. 2017, 35. [CrossRef]

54. Batlevi, C.L.; Frank, S.D.; Stewart, C.; Hamlin, P.A.; Matasar, M.J.; Gerecitano, J.F.; Moskowitz, A.J.; Hamilton, A.M.; Zelenetz, A.D.; Drullinsky, P.; et al. Phase I/II clinical trial of ibrutinib and buparlisib in relapsed/refractory diffuse large B-cell lymphoma, mantle cell lymphoma, and follicular lymphoma. J. Clin. Oncol. 2018, 36. [CrossRef]

55. Witzig, T.E.; Vose, J.M.; Zinzani, P.L.; Reeder, C.B.; Buckstein, R.; Polikoff, J.A.; Bouabdallah, R.; Haioun, C.; Tilly, H.; Guo, P.; et al. An international phase II trial of single-agent lenalidomide for relapsed or refractory aggressive B-cell non-Hodgkin's lymphoma. Ann. Oncol. 2011, 22, 1622-1627. [CrossRef] [PubMed]

56. Yang, H.; Xiang, B.; Song, Y.; Zhang, H.; Zhao, W.; Zou, D.; Lv, F.; Bai, O.; Liu, A.; Li, C.; et al. Zanubrutinib monotherapy for patients with relapsed or refractory non-germinal center diffuse large B-cell lymphoma: Results from a phase II, single-arm, multicenter, study. J. Clin. Oncol. 2020, 38. [CrossRef] 
57. de la Merino, L.C. Lenalidomide plus R-GDP (R2-GDP) in relapsed/refractory diffuse large B-cell lymphoma: Final results of the R2-GDP-GOTEL trial. J. Clin. Oncol. 2020, 38. [CrossRef]

58. Guerra-Bauman, F.; LaPlant, B.; Macon, W.R.; Witzig, T.E.; Farooq, U.; Nowakowski, G.S.; Feldman, T. Phase I/II study of R-ICE (rituximab-ifosfamide-carboplatin-etoposide) with lenalidomide (R2-ICE) in patients with first-relapse/primary refractory diffuse large B-cell lymphoma (DLBCL) in academic and community cancer research united (ACCRU) network. J. Clin. Oncol. 2020, 38. [CrossRef]

Publisher's Note: MDPI stays neutral with regard to jurisdictional claims in published maps and institutional affiliations.

(C) 2020 by the authors. Licensee MDPI, Basel, Switzerland. This article is an open access article distributed under the terms and conditions of the Creative Commons Attribution (CC BY) license (http://creativecommons.org/licenses/by/4.0/). 